\title{
YIELD COMPONENTS AS INDICATORS OF DROUGHT TOLERANCE OF SUGARCANE
}

\author{
Marcelo de Almeida Silva ${ }^{1 *}$; Jorge Alberto Gonçalves da Silva ${ }^{2} ; J^{\prime}$ an Enciso²;Vivek Sharma²; \\ John Jifon ${ }^{2}$ \\ ${ }^{1}$ APTA Pólo Centro-Oeste, Rod. Deputado Leônidas Pacheco Ferreira, km 304, C.P. 66 - 17201-970 - Jaú, \\ SP - Brasil. \\ ${ }^{2}$ Texas Agricultural Experiment Station, Texas A \& M University - 78596 - Weslaco, TX - USA. \\ *Corresponding author <marcelosilva@apta.sp.gov.br>
}

\begin{abstract}
Water deficit is one of the major factors limiting the production of sugarcane (Saccharum officinarum L.). A study of the effects of limited water condition on yield components and their relationship with productivity can aid breeding programs in selecting for high yielding genotypes under this condition. The objective of this study was to investigate the relationships among the parameters stalk number, stalk height, stalk diameter, and stalk weight with cane yield in sugarcane growing in a field under moderate water stress during its grand growth period, in order to provide information to help breeders in adopting traits for selecting drought tolerant varieties. Seventy-eight genotypes plus two controls, one drought-tolerant and one drought-susceptible, were grown under a moderate water deficit condition in the field in 2005/2006 at Weslaco, TX. Productivity and yield components were measured. Under stress, the tolerant control (TCP93-4245) showed higher productivity, stalk number, stalk height and stalk weight than the susceptible one (TCP87-3388). However, the susceptible control showed higher stalk diameter. Linear association was found between productivity and its yield components, but stalk diameter showed to be fairly unstable among genotypes. Stalk height showed significant correlation with stalk number, stalk diameter and stalk weight. Stalk diameter also showed positive correlation with stalk weight. Therefore, during the selection procedure, when one of these traits is enhanced by drought tolerance, the correlated trait should also increase, making it feasible to select genotypes with high productivity, stalk number, stalk height, and stalk weight under water deficit.
\end{abstract}

Key words: Saccharum spp., biometric attributes, productivity, water stress, genotypes

\section{COMPONENTES DE PRODUÇÃO COMO INDICADORES DE TOLERÂNCIA À SECA EM CANA-DE-AÇÚCAR}

RESUMO: A deficiência de água é um dos principais fatores que limitam a produção da cana-deaçúcar (Saccharum officinarum L.). Estudar os efeitos do estresse hídrico sobre os componentes de produção e sua relação com a produtividade pode ajudar os programas de melhoramento a selecionar genótipos produtivos sob essa condição. O objetivo deste estudo foi investigar as relações entre os caracteres número de colmos, altura de colmos, diâmetro de colmos e massa de colmos com a produtividade de cana-de-açúcar cultivada em uma área, sob deficiência moderada de água, durante o período de maior desenvolvimento, a fim de prover informações que auxiliem melhoristas na adoção de características para selecionar variedades tolerantes à seca. Foram cultivados 78 genótipos e dois padrões, um tolerante e outro sensível ao estresse hídrico, sob deficiência moderada de água em campo e durante o ano agrícola 2005/2006 em Weslaco, Texas, Estados Unidos. Produtividade e os componentes de produção foram avaliados. Sob estresse, o padrão tolerante (TCP93-4245) apresentou maior produtividade, número de colmos, altura de colmos e massa de colmos do que o padrão sensível (TCP87-3388). Entretanto, o padrão sensível apresentou maior diâmetro de colmos. Associação linear foi encontrada entre produtividade e seus componentes, mas diâmetro de colmos foi bastante instável entre os genótipos. Altura de colmos apresentou correlação positiva com número, diâmetro e massa de colmos. Diâmetro de colmos também apresentou correlação positiva com massa de colmos. Portanto, durante o processo de seleção, quando um desses componentes é melhorado para tolerância à seca, o componente correlacionado deverá também ser melhorado, tornando-se possível selecionar genótipos com elevada produtividade e número, altura e massa de colmos sob deficiência hídrica.

Palavras-chave: Saccharum spp., atributos biométricos, produtividade, estresse hídrico, genótipos

Sci. Agric. (Piracicaba, Braz.), v.65, n.6, p.620-627, November/December 2008 


\section{INTRODUCTION}

Drought is a major limitation to sustainable crop production worldwide because it affects simultaneously a varied number of morphological and physiological traits in plants. The traits correlated with drought tolerance are suitable indicators for selection of drought tolerant genotypes in breeding programs to reduce the impact of water deficit on crop yield.

For sugarcane, researches have concentrated on agronomic and physiological traits, which could lead to adaptation to these conditions or be correlated to drought tolerance and could be used for development of new varieties (Domaingue, 1995). One of the main problems associated with the development of drought tolerant varieties is the difficulty to identify single traits that can be used for selection (Quizenberry, 1982). Apart from that, the information on drought response among cultivars is generally gained after they have been released for commercial production (Inman-Bamber \& Smith, 2005), and only a few genotypes are compared (Domaingue, 1995).

Number of millable stalks is reduced under restricted water availability (Ramesh \& Mahadevaswamy, 2000; Robertson et al., 1999; Da Silva \& Da Costa, 2004; Singh \& Reddy, 1980; Soares et al., 2004). Stalk diameter is influenced by water regime; however, it can also be affected by genotype (Da Silva \& Da Costa, 2004). Cane elongation and stalk height are negatively and strongly affected by drought conditions (Inman-Bamber \& Smith, 2005; Ramesh \& Mahadevaswamy, 2000; Da Silva \& Da Costa, 2004; Singh \& Reddy, 1980; Soares et al., 2004). According with Domaingue (1995) and Soares et al. (2004), stalk height is the most severely reduced parameter under drought conditions. Thus, selection procedures should aim at identifying genotypes which are able to keep on elongating even in water stress conditions, with a view to increase cane height under these conditions. Finally, as a result of the reduction of the yield components, cane yield is decreased under water stress conditions (Inman-Bamber \& Smith, 2005; Ramesh, 2000; Ramesh \& Mahadevaswamy, 2000; Da Silva \& Da Costa, 2004; Singh \& Reddy, 1980; Soares et al., 2004; Wiedenfeld, 1995).

The objective of this study was to investigate the relationships of stalk number, stalk height, stalk diameter, and stalk weight with cane yield for sugarcane growing in a field under moderate water stress during its grand growth period in order to provide information to help breeders in adopting traits for selecting drought tolerant varieties.

\section{MATERIAL AND METHODS}

Eighty sugarcane genotypes were grown in a field experiment at Hiler Farm, near Weslaco, TX, USA $\left(26^{\circ} 12^{\prime} \mathrm{N}, 97^{\circ} 57^{\prime} \mathrm{W}\right.$, elevation $\left.18.90 \mathrm{~m}\right)$ to evaluate their tolerance to water stress, during the growing season of 2005-2006. The soil type at the experimental site was a sandy clay loam Typic Calciustolls. Singlenode stalk segments of each genotype were planted on November 14, 2005, in three-row plots, $3.0 \mathrm{~m}$ long and $1.50 \mathrm{~m}$ apart. Data were collected from the central row plants. Two irrigation treatments (well-watered or drought-stressed) were initiated at 180 days after planting. The fully irrigated treatment will be reference herein as wet and the moderate irrigation treatment as dry. The experiment was conducted in a randomized complete block design with four replicates within each irrigation treatment.

Among eighty genotypes, two were chosen as control varieties according to their behavior in relation to drought in the Rio Grande Valley region, Texas. TCP87-3388 was chosen as a drought susceptible cultivar and TCP93-4245 as a drought tolerant cultivar. The 78 remaining genotypes are from different American breeding programs, and they are in adaptation assessment phase to south Texas environmental conditions. These genotypes are original from CP (Canal Point, FL); $\mathrm{H}, \mathrm{HO}, \mathrm{HOCP}, \mathrm{L}, \mathrm{LCP}, \mathrm{RSB}$ and US (Houma and Baton Rouge, LA), TCP and TSP (Weslaco, TX).

The crop water requirements of the sugarcane were met for the wet treatment. Irrigation was monitored with a neutron probe (Model 503 DR Hydropobe Moisture Gauge, CPN Int. Inc., California, USA). One access tube was installed at each site (wet and dry) to a depth of $1.80 \mathrm{~m}$. Soil water was replenished at $80 \%$ depletion of the $45 \mathrm{~cm}$ layer. Some irrigations were skipped at the moderate water stress treatment to deliberately stress the sugarcane. This methodology was done in accordance to Ramesh (2000) and Ramesh \& Mahadevaswamy (2000). This condition was imposed from 180 to 270 days after planting, i.e. during the grand growth phase (Gascho \& Shih, 1983).

Monthly total rainfall, monthly total water applied to genotypes and mean air temperature during November of 2005 to January of 2007 are shown in Figure 1. The total amount of rainfall received during the cropping period was $568 \mathrm{~mm}$, while the irrigation amount applied between January and June was 184 $\mathrm{mm}$ and $300 \mathrm{~mm}$ on the dry and wet treatments, respectively. Thus, the total amount of water was 752 $\mathrm{mm}$ for the dry and $868 \mathrm{~mm}$ for the wet treatment.

Yield components, such as stalk number, stalk height, stalk diameter and stalk weight were evaluated for each genotype. The number of millable stalks was 
counted within each plot. For the determination of the stalk height, a measurement tape was used to measure a sample of six stalks. A Vernier caliper was used to measure the diameter of the same six stalks, which the reading region was defined as one third of the stalk height (from the basis to the top). Then, the six stalks were weighed, and the mean weight was obtained. The cane productivity was calculated from the weight of all millable canes per plot and the area occupied by each plot $\left(\mathrm{t} \mathrm{ha}^{-1}\right)$.

Data were subjected to analysis of variance, using a SPSS 13.0 statistical package. The significance of the factor effect was determined using the F-test, and to determine the significance of the difference between the means, least significance differences (LSD) were estimated by Tukey $(p<0.05)$.

\section{RESULTS AND DISCUSSION}

Stalk number, stalk height, stalk diameter, stalk weight, as well as productivity, were affected by genotypes and water regimes (Table 1). However, stalk di-

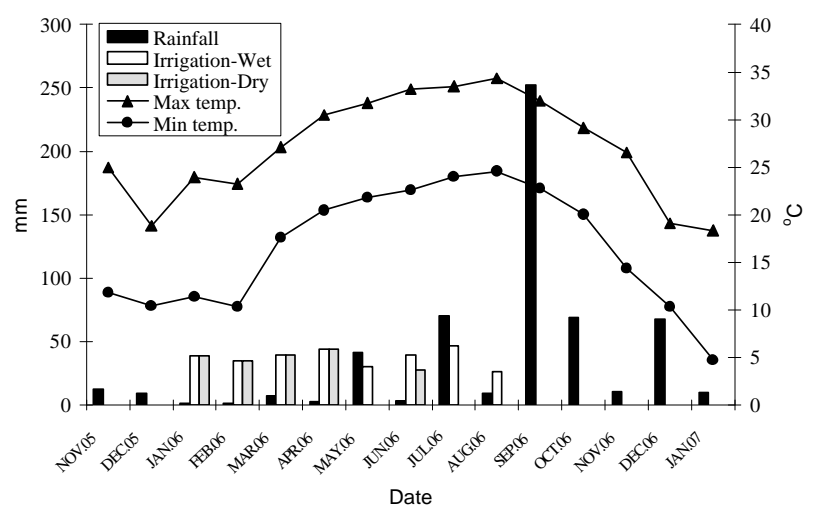

Figure 1 - Monthly total rainfall and irrigation for dry and wet treatments, and maximum and minimum mean air temperature between November/2005 and January/ 2007, in Weslaco, TX. ameter showed higher values under moderate water stress, while other characters showed higher values under well-watered treatment. The high significance value $(p<0.01)$ for all attributes shows that there is considerable variation for these traits among sugarcane genotypes in response to water deficit. The genotype $x$ water regime interaction was significant for stalk number, stalk weight and productivity at $p<0.01$ level, and for stalk height and stalk diameter $(p<0.05)$.

The stalk number for the wet treatment was higher than the dry treatment. The average stalk number per meter for the dry treatment was 10.92 compared to 12.99 for the wet treatment (Table 1). The number of stalks can be considered within the expected values for number of millable canes, i.e., between 10 to 14 tillers per meter (Castro \& Christoffoleti, 2005). The formation of tillers in sugarcane is important because of the contribution they make to yield by acting as a storage sink (Ramesh \& Mahadevaswamy, 2000). During its growth, sugarcane passes through four distinct physiological stages, named, germination, tillering, grand growth, and maturity (Gascho \& Shih, 1983). Tillering together with early grand growth are known as the formative phase, and this has been identified as a critical water-demand period. Stress during this phase affects the final yield (Naidu, 1976). Thus, the tillering ability and subsequent growth efficiency largely determine the yield of a given cultivar (Joshi et al., 1996). Higher tiller production, irrespective of environmental conditions or cultivar, leads to higher number of stalks at harvest, despite differences in tiller mortality (Soopramanien \& Julien, 1980).

Cane elongation and stalk height are negatively and strongly affected under drought conditions (Inman-Bamber \& Smith, 2005; Ramesh \& Mahadevaswamy, 2000; Da Silva \& Da Costa, 2004; Singh \& Reddy, 1980; Soares et al., 2004). In this study, the average stalk height for the 80-genotype of

Table 1 - F values means and coefficients of variation of five attributes measured in plant cane of eighty sugarcane genotypes in wet and dry treatments.

\begin{tabular}{|c|c|c|c|c|c|}
\hline Source & Stalk number & Stalk height & Stalk diameter & Stalk weight & Productivity \\
\hline & unit $\mathrm{m}^{-1}$ & $\mathrm{~cm}$ & $\mathrm{~cm}$ & $\mathrm{~kg}$ & $\mathrm{t} \mathrm{ha}^{-1}$ \\
\hline Rep & $6.12 * *$ & $42.51 * *$ & $19.95 * *$ & $21.85 * *$ & $20.48 * *$ \\
\hline Genotype (G) & $17.39 * *$ & $8.54 * *$ & $16.28 * *$ & $32.03 * *$ & $16.52 * *$ \\
\hline Water regime $(\mathrm{W})$ & $219.49 * *$ & $325.38 * *$ & $826.20 * *$ & $94.03 * *$ & $275.27 * *$ \\
\hline $\mathrm{G} \times \mathrm{W}$ & $2.90 * *$ & $1.44 *$ & $1.41 *$ & $1.86^{* *}$ & $3.20 * *$ \\
\hline Fully irrigated mean & $12.99 \mathrm{a}^{\dagger}$ & $192.69 \mathrm{a}$ & $2.36 \mathrm{~b}$ & $1.13 \mathrm{a}$ & $97.21 \mathrm{a}$ \\
\hline Limited irrigated mean & $10.92 \mathrm{~b}$ & $167.48 \mathrm{~b}$ & $2.78 \mathrm{a}$ & $1.03 \mathrm{~b}$ & $75.37 \mathrm{~b}$ \\
\hline C.V. $(\%)$ & 14.73 & 9.82 & 7.13 & 11.32 & 19.30 \\
\hline
\end{tabular}

$*$ and $* *=$ significant at $p<0.05$ and 0.01 , respectively. ${ }^{\dagger}$ Means within a column and having different letters are different $(0.05$ probability level). 
the moderate water stress treatment was $167.48 \mathrm{~cm}$, while it was $192.69 \mathrm{~cm}$ for the same genotypes of the wet treatment (Table 1). This result shows the strong effect of the lack of water on this trait and it is in accordance with Domaingue (1995) and Soares et al. (2004). Ramesh \& Mahadevaswamy (2000) obtained $177 \mathrm{~cm}$ from four genotypes, with moderate drought treatment applied between $60-150$ days after planting. And Da Silva \& Da Costa (2004) obtained the average of $263 \mathrm{~cm}$ for stalk height when water deficit treatment was applied during the third to sixth months of age on eight genotypes, while the average was of $300 \mathrm{~cm}$ on the irrigated side.

Stalk diameter response to water regime has been found to depend on the genotype (Da Silva \& Da Costa, 2004). In the present study, the genotype average was $2.78 \mathrm{~cm}$ for the dry treatment and 2.36 $\mathrm{cm}$ for the wet treatment (Table 1). In this study the reason that the dry treatment resulted in greater stalk diameter than the wet treatment could be attributed to the fact that sugarcane elongated more on the wet treatment. Therefore, the combination of all these agronomic traits could affect final yield, as observed by Bissessur et al. (2001). Ramesh \& Mahadevaswamy (2000) found the low value of $1.96 \mathrm{~cm}$ for four varieties under moderate drought from 60 to 150 days after planting.

Stalk weight was affected by the irrigation amount. The wet treatment resulted in higher weights than the dry treatment. The average stalk weight for genotypes of the dry treatment was $1.03 \mathrm{~kg}$ compared to $1.13 \mathrm{~kg}$ for the wet treatment (Table 1). The value obtained by Da Silva \& Da Costa (2004) was $1.29 \mathrm{~kg}$, and Ramesh \& Mahadevaswamy (2000) obtained 0.66 $\mathrm{kg}$, and Robertson et al. (1999) $0.41 \mathrm{~kg}$, however, all these authors worked with one or few genotypes.

Biometric agronomic traits are important components for formation of final production in sugarcane. The decisive production attributes for the formation of the agricultural potential are the combination of stalk height, stalk number and stalk diameter, whether the stalk density is considered equal to 1.0 (Landell \&
Silva, 2004). Thus, in a determined area, the yield would be the product of these components divided by spacing. This justifies the importance of these components in yield determination under drought conditions.

It is expected that all the above attributes are affected by drought stress, mainly in susceptible cultivars, and, consequently, the productivity will also be affected. For this trial the mean productivity was 75.37 $\mathrm{t} \mathrm{ha}^{-1}$ for the dry treatment and $97.21 \mathrm{t} \mathrm{ha}^{-1}$ for the wet treatment (Table 1). Da Silva \& Da Costa (2004) obtained $90.61 \mathrm{t} \mathrm{ha}^{-1}$, and Ramesh \& Mahadevaswamy (2000), $88.0 \mathrm{t} \mathrm{ha}^{-1}$, involving eight and four genotypes, respectively, under water stress. On the other hand, it was well above the 33.3 and $22.4 \mathrm{t} \mathrm{ha}^{-1}$ values obtained by Robertson et al. (1999) with two different genotypes. The reasonable mean productivity in our study is an indicative of some highly productive genotypes under deficit water regime. Analysis of the interrelations between yield attributes and productivity may explain the differential genotype responses.

Productivity was plotted against stalk number per meter in Figure 2. A linear relationship between stalk productivity at final harvest and stalk number per meter explains $46 \%$ of the variation for the dry (Figure $2 a$ ) and $52 \%$ for the wet treatment (Figure 2b). The tolerant genotype TCP93-4245 presented productivity of $102.19 \mathrm{t} \mathrm{ha}^{-1}$ and stalk number of 14.44 per meter under dry conditions (Figure 2a), while a productivity of $131.78 \mathrm{t} \mathrm{ha}^{-1}$ and stalk number of 15.83 per meter on the wet site (Figure 2b). The susceptible genotype TCP87-3388 had productivities of $49.67 \mathrm{t} \mathrm{ha}^{-1}$ and $54.26 \mathrm{t} \mathrm{ha}^{-1}$ and stalk number of 8.94 and 9.76 per meter on the dry and wet treatments (Figures 2a, and $2 b$ ), respectively, suggesting that these two traits are positively associated. The control genotypes (tolerant and susceptible) confirmed its classification, because in accordance to Silva et al. (2007), a tolerant genotype would be one that has an above average value in both favourable (irrigated) as well as unfavourable (rainfed) conditions and a susceptible one shows below average values in both superior and inferior envi-
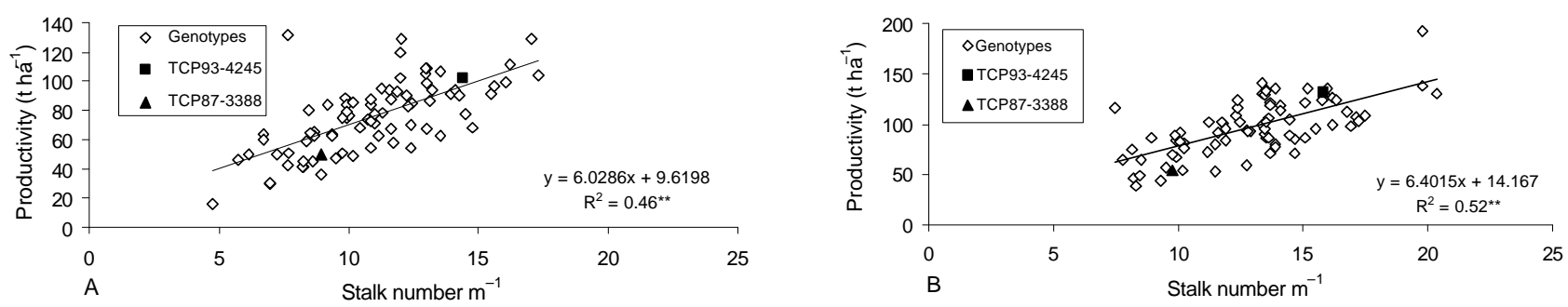

Figure 2 - Relationship between productivity and stalk number per meter in drought tolerant (TCP93-4245), drought sensitive (TCP873388 ) and 78 sugarcane genotypes under dry (a) and wet (b) treatments. ** significant at $p<0.01$. 
ronments, besides they can be considered good indicators of the stalk number response to water stress.

On the dry treatment (Figure 2a), the highest stalk number per meter, 17.06, was associated with the third highest productivity, $128.91 \mathrm{t} \mathrm{ha}^{-1}$, while the lowest stalk number, 4.76, was associated with the lowest productivity, $15.42 \mathrm{t} \mathrm{ha}^{-1}$. The highest productivity corresponded to stalk number of 7.63 , which is not so high but total productivity was based collectively on all attributes, and it was not considered in function of only one attribute. The data points also illustrate that gains on productivity can be obtained by selecting high stalk number genotypes, considering that genotypes with higher stalk number can be associated with higher productivity under water stress.

A linear relationship was identified between productivity and stalk height (Figures $3 a$ and $3 b$ ). The linear regression explained $37 \%$ of the variation for the moderate stress treatment and $35 \%$ for the wet treatment. For the dry (Figure 3a), the productivity of the drought tolerant genotype TCP93-4245 (102.19 t ha-1) was plotted against $154.31 \mathrm{~cm}$ of stalk height, while the productivity of susceptible genotype TCP87-3388 (49.67 $\mathrm{t} \mathrm{ha}^{-1}$ ) had a relationship with $146.38 \mathrm{~cm}$ of stalk height. For the wet treatment (Figure 3b), the drought tolerant control presented stalk height of $199.03 \mathrm{~cm}$ and productivity of $131.78 \mathrm{t} \mathrm{ha}^{-1}$, while the susceptible control had $168.71 \mathrm{~cm}$ and productivity of $54.26 \mathrm{t} \mathrm{ha}^{-1}$. For the stalk height attribute of the dry treatment, the highest productivity among the 80 genotypes was $131.08 \mathrm{t} \mathrm{ha}^{-1}$, and it was associated with the highest stalk height of $222.27 \mathrm{~cm}$, while the low-

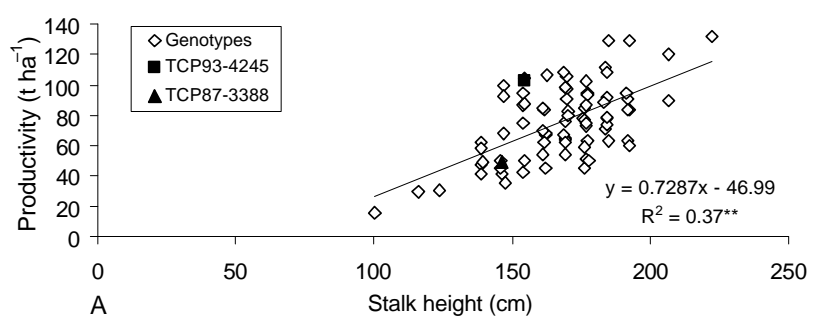

est productivity was $15.42 \mathrm{t} \mathrm{ha}^{-1}$, associated with the lowest height value of $100.51 \mathrm{~cm}$. This is consistent with the findings of Da Silva \& Da Costa (2004) and Ramesh \& Mahadevaswamy (2000), who reported that under drought conditions the highest height values always were associated with the most productive genotypes, and the lowest productive genotypes showed the lowest stalk height values. The slope of both dry and wet treatments were very similar. The wet treatment produced higher stalks as consequence of more applied water. The control genotypes captured the effect of stalk height to water stress and can be used as indicators of water stress.

More variation was observed between productivity and stalk diameter in response to treatments and only $23 \%$ of the variation could be explained with this agronomic attribute for moderate water stress (Figure 4a) and $13 \%$ for the wet treatment (Figure 4b), probably indicating that there is less influence of irrigation on stalk diameter. For the dry treatment, the productivity of the tolerant genotype control, TCP93-4245, was $102.19 \mathrm{t} \mathrm{ha}^{-1}$ corresponding to a stalk diameter of $2.68 \mathrm{~cm}$, which was lower than the diameter showed by the susceptible control TCP87-3388 (2.78 $\mathrm{cm})$. The most productive genotype under this moderate treatment had the highest diameter $(3.94 \mathrm{~cm})$, and the lowest productive genotype presented a diameter of $2.31 \mathrm{~cm}$, which was third to lowest. The lowest stalk diameter $(2.15 \mathrm{~cm})$ was associated with the productivity of $54.13 \mathrm{t} \mathrm{ha}^{-1}$. However, on the wet site (Figure 4b), the tolerant control had a stalk diameter $(2.33 \mathrm{~cm})$ higher than the susceptible control (2.11

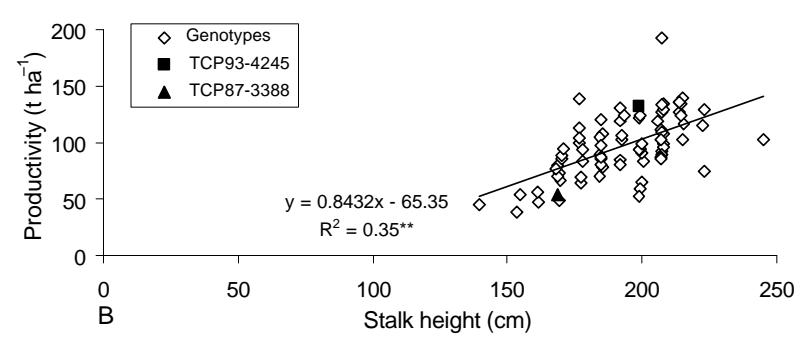

Figure 3 - Relationship between productivity and stalk height in drought tolerant (TCP93-4245), drought sensitive (TCP87-3388) and 78 sugarcane genotypes under dry (a) and wet (b) treatments. ** significant at $p<0.01$.
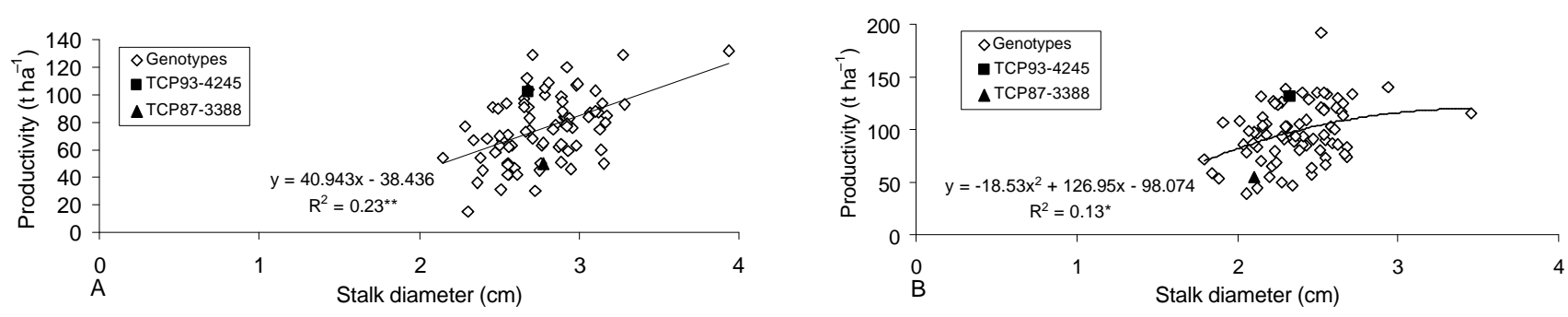

Figure 4 - Relationship between productivity and stalk diameter in drought tolerant (TCP93-4245), drought sensitive (TCP87-3388) and 78 sugarcane genotypes under dry (a) and wet (b) treatments. ** significant at $p<0.01$ and $*$ significant at $p<0.05$. 
$\mathrm{cm})$. This data shows a wide genotype response to water in relation to this attribute and the control genotypes were not able to reflect stalk diameter changes as result of water stress. Domaingue (1995) reported that cane diameter has a slight increase or maintains unaltered under unirrigated conditions, which means that this parameter is fairly unstable across water treatments and, consequently, selection should be addressed to other more important parameters.

Under dry conditions (Figure 5a), the tolerant control (TCP93-4245) presented a productivity of $102.19 \mathrm{t} \mathrm{ha}^{-1}$ that corresponded to the stalk weight of $1.06 \mathrm{~kg}$, while in the drought sensitive control (TCP87-3388), a productivity of $49.67 \mathrm{t} \mathrm{ha}^{-1}$, associated to the stalk weight of $0.82 \mathrm{~kg}$. A common linear relationship was identified between productivity and stalk weight, with a coefficient of determination of $43 \%$. The highest productive genotype showed the highest stalk weight value, $2.59 \mathrm{~kg}$, and the lowest productivity corresponded to the lowest stalk weight, $0.45 \mathrm{~kg}$. For the wet treatment (Figure 5b), the tolerant genotype control had average stalk weight of $1.24 \mathrm{~kg}$ for a productivity of $131.78 \mathrm{t} \mathrm{ha}^{-1}$, and the susceptible control presented $0.83 \mathrm{~kg}$ of stalk weight with a productivity of $54.13 \mathrm{t} \mathrm{ha}^{-1}$, and the same relationship of $43 \%$ was identified between productivity and stalk weight (Figure 5b). In a study with eight genotypes under water deficit conditions, Da Silva \& Da Costa (2004) also found similar relations between these two parameters, showing that the most productive genotype had the highest stalk weight value and, on the other hand, the lowest productive genotype the

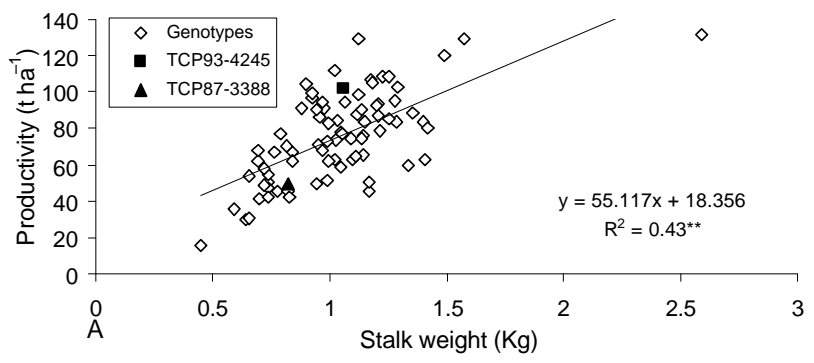

lowest stalk weight. Although correlation coefficients were low, regressions were highly significant, indicating an agronomic response of stalk weight to water deficits.

Selection in breeding programs based on secondary traits associated with tolerance to water stress is known to be useful (Ludlow \& Muchow, 1990). Stalk number, stalk height, stalk diameter and stalk weight are traits affected by environmental changes. However, they are also heritable (Skinner, 1967). It is clear that an ideal secondary trait for selection purpose should be inexpensive and rapid to measure, in addition to being heritable (Altinkut et al., 2001). However, Da Silva \& Da Costa (2004) reported that these parameters are very important in yield determination under water deficit conditions, but the response can vary for different genotypes.

Besides the association with productivity, it was also determined whether under moderate water deficit conditions a certain biometric trait is correlated with other putative drought tolerant biometric traits (Table 2). Under moderate water stress, productivity showed positive correlations with stalk height, stalk number, stalk diameter and stalk weight. A higher proportion of cane productivity was attributed to a combination of parameters than to any single parameter. Da Silva \& Da Costa (2004) also found significant positive correlation among productivity and stalk height and stalk weight, but a moderate positive correlation was found between productivity and stalk number, and no significant correlation to productivity versus stalk diameter. Probably the lack of complete accordance

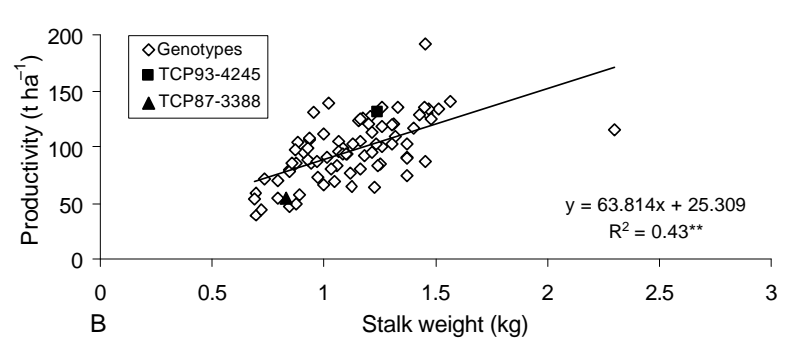

Figure 5 - Relationship between productivity and stalk weight in drought tolerant (TCP93-4245), drought sensitive (TCP87-3388) and 78 sugarcane genotypes under dry (a) and wet (b) treatments. ${ }^{*} *$ significant at $p<0.01$.

Table 2 - Correlation matrix between stalk number, stalk height, stalk diameter, stalk weight and productivity in sugarcane genotypes under dry treatment.

\begin{tabular}{|c|c|c|c|c|}
\hline Source & Stalk Number & Stalk Diameter & Stalk Weight & Productivity \\
\hline Stalk height & $0.169 * *$ & $0.360 * *$ & $0.671 * *$ & $0.573 * *$ \\
\hline Stalk number & & $-0.173 * *$ & -0.054 & $0.640 * *$ \\
\hline Stalk diameter & & & $0.818 * *$ & $0.462 * *$ \\
\hline Stalk weight & & & & $0.642 * *$ \\
\hline
\end{tabular}

**significant at $p<0.01$. 
Table 3 - Correlation matrix between stalk number, stalk height, stalk diameter, stalk weight and productivity in sugarcane genotypes under wet treatment.

\begin{tabular}{lcccc}
\hline Source & Stalk Number & Stalk Diameter & Stalk Weight & Productivity \\
\hline Stalk height & $0.186^{* *}$ & 0.097 & $0.631^{* *}$ & $0.567^{* *}$ \\
Stalk number & & $-0.183^{* *}$ & -0.041 & $0.708^{* *}$ \\
Stalk diameter & & $0.586^{* *}$ & $0.248^{* *}$ \\
Stalk weight & & & $0.645^{* *}$ \\
\hline
\end{tabular}

**significant at $p<0.01$.

of the results can be explained by the big difference in the number of genotypes assessed in the two studies.

Stalk height showed significant correlation with stalk number, stalk diameter and stalk weight, and stalk diameter had also a positive correlation with stalk weight. Thus, during the selection procedure, when one of these traits is enhanced by drought tolerance, the correlated trait should also increase. And, consequently, it should be possible to select genotypes under water deficit with high productivity, stalk number, stalk height, stalk diameter and stalk weight. On the other hand, stalk number was negatively correlated with stalk diameter and showed moderate negative correlation with stalk weight. Therefore, selection aiming at increasing stalk number should lead to reduced stalk diameter.

Under wet conditions (Table 3) the values of correlation between the attributes were well similar to the dry treatment, except for the correlation between stalk height and stalk diameter, which had a no significant correlation (0.097). All these observations demonstrate that certain sugarcane traits can provide useful tools for breeding programs for the selection of higher genotypes under drought conditions. Bissessur et al. (2001) did not find any correlation between stalk height and stalk diameter for both wet and dry treatments. And for this reason, selection for cane yield should be made with special attention to stalk number and stalk height for dry site.

\section{CONCLUSIONS}

It is possible to select sugarcane genotypes under moderate water deficit conditions with higher productivity associated with higher stalk number, stalk height and stalk weight. Therefore, these traits could be considered as useful tools during crop breeding procedure in order to make this process more rapid and cheaper. Besides, this information should be used in hybridization programs to find parents with higher ability to transfer drought tolerance as expressed in agronomic traits.

\section{ACKNOWLEDMENTS}

To the Rio Grande Valley Sugar Growers, Inc. (RGVSG) for financial support, and to CNPq for the pos-doctorate fellowship (201076/2005-5) granted to the first author.

\section{REFERENCES}

ALTINKUT, A.; KAZAN, K.; IPEKCI, Z.; GOZUKIRMIZI, N. Tolerance to paraquat is correlated with the traits associated with water stress tolerance in segregating $\mathrm{F}_{2}$ populations of barley and wheat. Euphytica, v.121, p.81-86, 2001.

CASTRO, P.R.C.; CHRISTOFFOLETI, P.J. Fisiologia da cana-deaçúcar. In: MENDONÇA, A.F. (Ed.) Cigarrinhas da cana-deaçúcar: controle biológico. Maceió: Insecta, 2005. cap.1, p.3-48.

BISSESSUR, D.; TILNEY-BASSETT, R.A.E.; CHONG, L.C.Y. Genetic potential of sugarcane progenies grown in the extremely wet and dry environments in Mauritius. Sugar Cane International, v.19, p.5-10, 2001.

DA SILVA, A.L.C.; DA COSTA, W.A.J.M. Varietal variation in growth, physiology and yield of sugarcane under two contrasting water regimes. Tropical Agricultural Research, v.16, p.1-12, 2004.

DOMAINGUE, R. Family and varietal adaptation of sugarcane to dry conditions and relevance to selection procedures. In: INTERNATIONAL SOCIETY OF SUGAR CANE TECHNOLOGISTS CONGRESS, 21., Bangkok, 1995. Proceedings. Bangkok: ISSCT, 1995. p.418-435.

GASCHO, G.J.; SHIH, S.F. Sugarcane. In: TEARE, I.D.; PEET, M.M. (Ed.) Crop water relations. New York: John Wiley, 1983. p.445-479.

INMAN-BAMBER, N.G.; SMITH, D.M. Water relations in sugarcane and response to water deficits. Field Crops Research, v.92, p.185-202, 2005.

JOSHI, S.; JADHAV, S.B.; PATIL, A.A. Effect of tiller pruning on cane and sugar yield in early maturing sugarcane varieties. In: ANNUAL CONVENTION OF THE DECCAN SUGAR TECHNOLOGISTS ASSOCIATION, 45., Pune, 1996. Proceedings. Pune: DSTA, 1996. p.24-28.

LANDELL, M.G.A.; SILVA, M.A. As estratégias de seleção da cana em desenvolvimento no Brasil. Visão Agrícola, v.1, p.18-23, 2004.

LUDLOW, M.M.; MUCHOW, R.C. A critical evaluation of traits for improving crop yield in water-limited environments. Advances in Agronomy, v.43, p.107-153, 1990.

NAIDU, K.M. Annual report. Coimbatore: Sugarcane Breeding Institute, 1976. 89p.

QUIZENBERRY, J.E. Breeding plants for drought tolerance and plant water use efficiency. In: CHRISTIANSEN, M.N.; LEWIS, C.F. (Ed.) Breeding plants for less favorable environments. New York: Wiley-Interscience,1982. p.193-212.

RAMESH, P. Effect of different levels of drought during the formative phase on growth parameters and its relationship with dry matter accumulation in sugarcane. Journal of Agronony \& Crop Science, v.185, p.83-89, 2000. 
RAMESH, P.; MAHADEVASWAMY, M. Effect of formative phase drought on different classes of shoots, shoot mortality, cane attributes, yield and quality of four sugarcane cultivars. Journal of Agronomy \& Crop Science, v.185, p.249-258, 2000.

ROBERTSON, M.J.; INMAN-BAMBER, N.G.; MUCHOW, M.C.; WOOD, A.W. Physiology and productivity of sugarcane with early and mid-season water deficit. Field Crops Research, v.64, p.211-227, 1999.

SILVA, M.A.; SOARES, R.A.B.; LANDELL, M.G.A.; CAMPANA, M.P. Agronomic performance of sugarcane families in response to water stress. In: INTERNATIONAL SOCIETY OF SUGAR CANE TECHNOLOGISTS CONGRESS, 26., Durban, 2007. Proceedings. Durban: ISSCT, 2007. p.613-623.

SINGH, S.; REDDY, M.S. Growth, yield and juice quality performance of sugarcane varieties under different soil moisture regimes in relation to drought resistance. In: INTERNATIONAL SOCIETY OF SUGAR CANE TECHNOLOGISTS CONGRESS, 17., Manila, 1980. Proceedings. Manila: ISSCT, 1980. p.541-555.

SKINNER, J.C. Grading varieties for selection. In: INTERNATIONAL SOCIETY OF SUGAR CANE TECHNOLOGISTS CONGRESS, 12., Santurce, 1967. Proceedings. Santurce: ISSCT, 1967. p.938-949.
SOARES, R.A.B.; OLIVEIRA, P.F.M.; CARDOSO, H.R. ; VASCONCELOS, A.C.M.; LANDELL, M.G.A.; ROSENFELD, U. Efeito da irrigação sobre o desenvolvimento e a produtividade de duas variedades de cana-de-açúcar colhidas em início de safra. STAB Açúcar, Álcool e Subprodutos, v.22, p.38-41, 2004.

SOOPRAMANIEN, G.C.; JULIEN, M.H.R. Physiological basis of yield variation between and within sugarcane varieties grown under contrasting environments. II. The evolution of tiller density in relation to yield and harvest. In: INTERNATIONAL SOCIETY OF SUGAR CANE TECHNOLOGISTS CONGRESS, 17., Manila, 1980. Proceedings. Manila: ISSCT, 1980. p.516524.

WIEDENFELD, R.P. Effects of irrigation and N Fertilizer application on sugarcane yield and quality. Field Crops Research, v.43, p.101-108, 1995.

Received June 18, 2007

Accepted May 06, 2008 